\title{
PRHLG POZNAVANJU INTENZITETA PRIRASTA PRASADI VELIKE BELE ENGLESKE SVINJE U DOBA SISANJA
}

\author{
Sadržaj: Uvod - Materijal i metoda rada - Ishrana krmača \\ i prasadi za vreme dojenja - Trajanje bredosti, \\ broj prasadi u leglu, mortalitet prasadi - Gubitak \\ telesne težine krmača u doba dojenja - Razvitak \\ telesne težine prasadi do kraja osme nedelje - \\ Zaključak - Zusammenfassung - Literatura.
}

\section{Uvod}

Po desetogodišnjem olijentacionom programu unapređenja stočarstva hole ranostasne svinje treba da se gaje u svim oblastima FNR Jugoslavije: nizinskim, brdskim, planinskim i primorskim. Odavno se bele svinje gaje u Sloveniji, Dalmaciji, Crnoj Gori, dok se u Bosni i Hercegovini rede sretaju. Svinjarstvo je uopšte u NR Bosni i Hercegovini slabo razvijeno i brojno i kvalitativno. Glavni je razlog ovoj zaostalosti, što se pod turskom i austriskom upravom, kao i u staroj Jugoslaviji, iz verskih i politickih motiva, nije radilo na podizanju svinjarstva. Danas ne postoje ovi razlozi i narodne vlasti treba da sistematski i po utvrdenom planu potpomažu i usmeravaju razvitak svinjarstva. Besumnje, biće velikih poteškoća u podizamju i unapredenju svinjarstva u Bosni i Hercegovini, pogotovo u tome da se uvedu i održe kultume rase, kao što su bele engleske svinje. Za ovu granu stocarstva narod nema tradicije, ishrana svinja je nepravilna, a higijenske prilike, svinjci, naxin drżanja i nega primitivni.

Poznato je staro mišljenje obazrivih stočara, da se u prilikama loše ishrane i nege ne mogu održati kulturne rase stoke, te se iz toga izvodi zaključak da treba drźati proste, domaće rase, a strane uvoditi oprezno i postepeno, sa stvaranjem boljih životnih uslova, koje one zahtevaju. To znači jos neodredeno vreme cekati na takve uslove za uvodenje kulturnih rasa svinja u Bosnu i Hercegovinu. Međutim, mi imamo vlastitih jskustava da se bolji uslovi mogu stvarati naporedo sa uvodenjem kulturnih rasa. $\mathrm{Na}-$ primer, kada su prve engleske bele svinje uvezene u Crnu Goru (narod im je dao ime pulijeske svinje), one nisu došle u narocito povoljne uslove nege, ishrane i smeštaja, a ipak su se održale $\mathfrak{i}$ vremenom su ukrštanjem s domacom prostom svinjom stvorile tip bele ranostasne svinje. Bela svinja u Crnoj Gori dobro se aklimatizovala i potisnula je autohtonu svinju. Ona se odlikuje znatnom plodnošcu i visokom produkcijom kvalitetne slanine i mesa.

U doba kada se preporucuje uvođenje engleskih belih svinja u NR Bosnu i Hercegovinu, smatramo da je potrebno, izmedu ostalog, da se ustanovi, kako se one prilagodavaju novim uslovima i kako se razvija njihov podmladak. Od brzine razvitka prasadj zavisi dalji uspeh u gajenju svinja. Svakako je veliki manjak ovih ispitivanja sto se radilo $s$ malim brojem prasadi. Ipak se nadamo da ce 1 ovi skromni podaci poslužiti gajačina kao orjjentacija i kontrola liěnih uspeha. 


\section{Materijal za ispitivanje i metod rada}

Ispitivanja su vršena na Fakultetskom oglednom poljoprivrednom dobru Slatina, kod Sarajeva. U novembru 1950 godine Fakultetsko dobro nabavilo je iz Kamendina (Backa) tri krmačice i jednog nerasta velike bele engleske rase. Svinje su bile stare oko 12 meseois sa prosečnom živom težinom od $90 \mathrm{~kg}$ za krmačice i $120 \mathrm{~kg}$ za nerasta. Težina prema starosti nije odgovarala standardu rase. Nerast i jedna krmačioa imali su po 14 a dve krmačice po 12 sisa.

Prasad su oprašena u proleće 1951 i u proleće 1952 godine. Ukupno je ispitivano 59 grla (23 muških i 36 ženskih). Označavanje prasadi je izvršeno rovašenjem. Prasad su vagana istog dana posle prašenja, a kasnije svakog sedmog dana, do kraja osme nedelje, kada su odlučena. Vaganje je vršeno na dvokrakom kantaru. Krmače su vagane redovno kada i prasci, $i$ to na obiynoj decimalnoj vazi.

S obzirom na mali broj grla srednja vrednost je izracunata aritmetičkim putem, a srednja greška za srednju vrednost po Ta v̌ a r ovoj formuli modificirane Peterove metode

$$
m_{M}=\frac{E( \pm D)}{n \sqrt{n}-1}
$$

\section{Ishrana i način drŭanja krmača i prasadi za vreme dojenja.}

Ishrana krma ča U drugoj polovini suprasnosti krmace su dcbijale dnevno po tri kilograma koncentrata (pšenične mekinje i ječmena prekrupa). Prve cetini nedelje dojenja obrok je sastavljen iz $7 \mathrm{~kg}$ koncentrata $(6 \mathrm{~kg}$ sitnih pšeničnih mekinja i $1 \mathrm{~kg}$ ječmene prekrupe), $1 \mathrm{~kg}$ punog kravljeg mleka i $1 \mathrm{~kg}$ zelenog kupusa. Od $5-8$ nedelje davana je ista količina $i$ vrsta koncentrata, bez mleka, a mesto kupusa zelena lucerka po volji. Nastojalo se da krmače zadrže apetit i da mnogo ne izgube na težini, što je i postignuto. Kod dojenja drugog legla (1852 god.) obrok koncentrata bio je isti, mleko nije davano, a soćna hrana je davana u vidu repe ili stočnog kelja.

Ishrana pras a di. Prve dve nedelje prasci nisu nista dobijali osim majcino mleko. Treće nedelje imali su na raspolaganju drveni ugalj, kredu i koncentrate (0,5 kg ječmene prekrupe na leglo). Cetvrte nedelje neznatno je povećan obrok koncentrata, a od pete nedelje davano je po grlu na dan $0,25 \mathrm{~kg}$ jecmene prekrupe meko zamešane u hladnoj vodi. Prasci su redovno pojeli ceo obrok. Uz koncentrate prasci su dobijali po volji mladu nakosenu lucerku.

Nacin držnaja krmača i prásadi. Svaka krmaxa imala je zasebnu kolibu, gradenu iz dasaka, sa. $6 \mathrm{~m}^{2}$ poda. Pred kolibom je tvrdi ispust za hranjenje, iza kolibe je mekani ispust. Ni krmače ni prasci nisu izlazili iz ispusta, niti su koristili paš. Rano s proleća, kada je vreme bilo hladno i kisovito, prasci su se zadržavali u kolibama. 


\section{Trajanje bređosti, broj prasadi u leglu, mortalitet prasadi}

Trajanje bređosti. Krmačice su prvi put pripustene pod nerasta u decembru 1950 godine, a drugi put u oktobru 1951 godine. Od prvog prašenja do drugog pripuštanja prošlo je šest meseci, kako bi se dala mogućnost krmačicama da se telesno razviju i nadoknade zaostatak u porastu. Bređost je trajala 113 dana (110-116). Krmače su prvo leglo nosile prosečno dva dana duže nego drugo leglo.

Broj prasadi u leglu zavisi od rase, individue, starosti krmace, od nerasta, od kondicije. Ko din e c (4) je ustanovio za srednje engleske bele svinje (na selekcijskim svinjogojskim stanicama u Hrvatskoj) 8,98 prasadi u leglu. J. S ch midt (12) za nemacku plemenitu svinju 9,6 (1-17), za nemačku oplemenjenu 10,3 (1-22). Il an č ić (3) za berksire u Pivnicama 8,46 (2-15). Kod naših pet legla prosek je 11,8 prasadi (11-14). Prva legla imaju prosek 12, a druga legla 11,5 grla.

K Y̌ iženecký (6) je kod nemacke plemenite svinje ustanovio da se broj prasadi u leglu povećava i dostiže maksimum u IV leglu, a kod nemacke oplemenjene u VI leglu.

Mortalitet prasadi. Uginjavanje prasadi na sisi zavisi od više faktora: rase, starosti krmače, higijenskih uslova, ishrane, godisnjeg doba. Prasci kulturnih rasa osetljiviji su. Mlade krmace, prveskinje, nemaju dovoljno razvijen instinkt materinstva, pa češće prignjeð̌e prasad. Zimi je teže udovoljiti životnim zahtevima, usled čega se povećava smrtnost. U proleće i leti, kod pašnjačkog držanja svinja, ishrana je pravilnija $i$ bolja, čime se povećava otpornost prasadi.

Kodinec je kod engleskih belih svinja ustanovio mrtvorođenih 4,5 procenta. W. S mith (14) za americke rase 5,2, a ukupno uginulih i mrtvorođenih u doba sisanja 34,4 procenta. Kod našeg ogleda na 59 prasadi jedno je mrtvo oprašeno, a Sestoro su krmace prignječile prvih sedam dana dojenja. Mrtvorodenih je 1,7 procenata. Ukupno mrtvorođenih i prignječenih 11,8 procenata. Više nije bilo gubitaka do kraja osme nedelje.

\section{Gubitak telesne težine krmă̌a za vreme dojenja}

Gubitak telesne težine krmača zavisi od mlečnosti krmace, broja prasadi u leglu, ishrane krmače i skorišćavanja hrane. Smatraju se kao dozvoljeni gubici $6,5-7,5$ procenata.

Kodine c (5) kod velikih engleskih belih svinja ima najveći gubitak telesne težine od $40 \mathrm{~kg}$. Neke krmače su dobile u težini. $\mathrm{S} \mathrm{m}$ ith navodi da su krmače za vreme dojenja od 8 nedelja izgubile 10 procenata (po 20,412 kg od 204,12 kg). Kod našeg ogleda gubitak telesne težine zk osam nedelja dojenja iznosio je prosečno po $19,5 \mathrm{~kg}$ ili 13,5 procenata. Krmače su neposredno posle prašenja imale živu težlnu prosečno po $146,5 \mathrm{~kg}$. Najmanji gubitak bio je kod prveskinja, po $5 \mathrm{~kg}(2-9)$. 


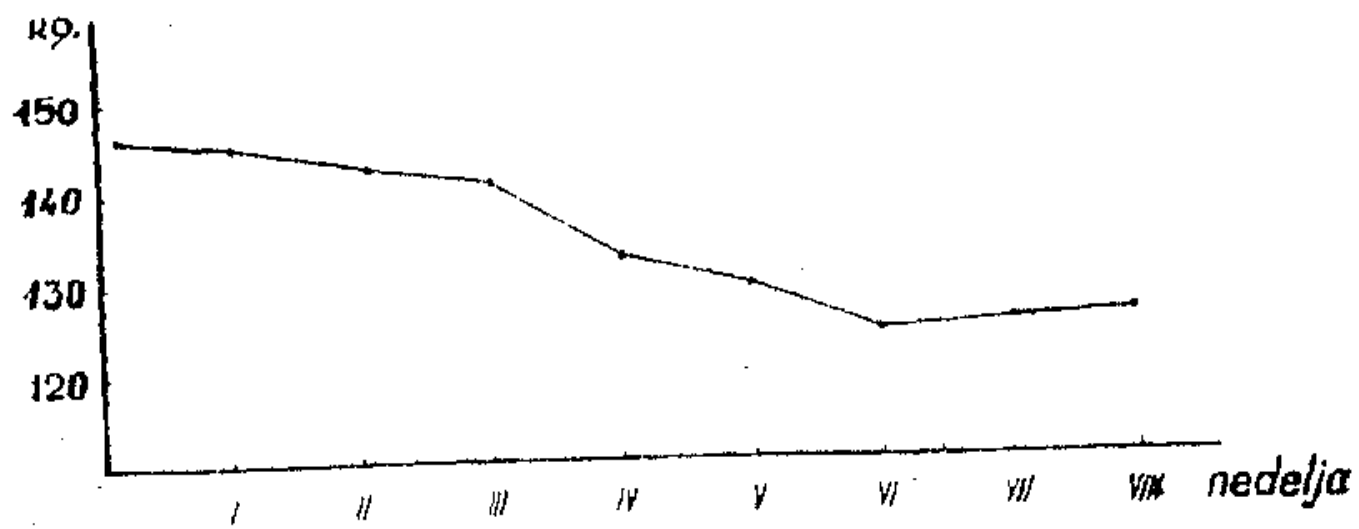

Dijagram br. 1. Gubjtak telesne težine krunača za 8 nedelja dojenja

\section{Povećanje telesne težine prasadi do kraja osme nedelje}

Na povećanje telesne težine prasadi i njihov razvitak u doba sisanja utič mnogi faktori: živa težina jednodnevne prasadi, spol, ishrana krmaca i prasadi, smeštaj, higijenske prilike, način držanja, starost krmače.

Ziva težina jednodnevne prasadj veoma varira, ne samo u rasi već $i$ kod iste krmace, $u$ istom leglu, $S c h m i d t, L a u p-$ $\mathrm{rech}$ t, Sta ubes a d (13) konstatovali su varijaciju od $250-2,280 \mathrm{gr}$. Najmanja težina živog praseta iznosila je $400 \mathrm{gr}$. U njihovom ogledu prosec̆na težina prasadi nemačke plemenite rase je $1,242 \mathrm{gr}$, nemačke oplemenjene $1,310 \mathrm{gr}$, berkšira $1,111 \mathrm{gr}$, srednje bele engleske svinje 1,079 $\mathrm{gr}$. Richter (citirano po Ogr'izeku 10) ima prosečnu težinu za nemačku oplemenjenu svinju $1,440 \mathrm{gr}$ a za nemačku plemenitu 1,124 gr. Kod našeg ogleda težina jednodnevne prasadi iznosi $1,139 \mathrm{gr}$ (7001,600). Na živu težinu jednodnevne prasadi prema $\mathrm{Smith} u$ utiču: spol, starost krmače, ukrštanje, broj prasadi u leglu, vigor 'krmače i nerasta za vreme oplodnje, ishrana fetusa.

Uticaj s pola, Ogrizeḱ (i0) je za turopoljsku prasad ustanovio da je težina jednodnevnih ženskih grla skoro ista kao i muških (ž. - 1,260 m. - $1,270 \mathrm{gr}$ ). Do istih rezultata je dosa i B el ic (1) za lasastu mangulicu (ž. - 1,280, m. - $1,290 \mathrm{gr}$ ). R o m i ć (11) za belu mangulicu kaže da muška grla imaju nešto veću težinu od ženskih. La l e vić (8) je za resavku konstatovao da su ženska grla $80 \mathrm{gr}$ lakša od muških (ž. - 1,090, m. - 1,170). Kod moravke nije našao razliku u težini između muških i Zenskih grla. Richter za nemacku plemenitu svinju navodi da su ženska grla 20 gr lak.ša od muških. $\mathrm{S}$ m i th takođe za američke rase daje podatke, po kojima su muška grla teža $(1,170: 1,130)$.

Uopste podaci iz literature govore u korist muških grla i kao pravilo važi da su jednodnevna muska prasad teža od ženskih. U našem ogledu mušska grla su $109 \mathrm{gr}$ lakša od ženskih $(1,074: 1,183)$. Ovo tumacimo time sto je ispitivan mali broj prasadi (n - 59), sa više zenskih nego muških grla $(36: 23)$ i sto su u konačnom reżultatu odlučila dva legla sa prosec- 
nom težinom od $1,330 \mathrm{gr}$ u kojima je bilo 16 ženskih i 7 muških grla. Inače, kod tri legla muški su bili teži od ženskih, u jednom leglu težina je bila ista, a samo u jednom leglu ženska prasad su bila teža od muških $(1,433: 1,325)$.

Uticajstarosti krma č na živu težinu jednodnevne prasadi. Romić je za belu mangulicu ustanovio da prveskinje daju prasce sa proseřnom težinom od $1,310 \mathrm{gr}$ a u VII leglu od $1,600 \mathrm{gr}$. $\mathrm{S} \mathrm{mi}$ i h za americke rase navodi da su prasci od mladih krmača teški 1,070 gr a od starijih 1,100 gr. Kr r ižene cký je za nemačku plemenitu i za nemačku oplemenjenu svinju ustanovio da sa starošću krmaðe raste broj prasadi u leglu, alì prosečna težina prasadi ostaje konstantna Do istih rezultata su došli $S \mathrm{chmidt}$, La uprecht, $\mathrm{S}$ taubesand za nemačku oplemenjenu svinju.

U našem ogledu smo ustanovili da su prasci iz prvog legla sitniji nego iz drugog $(1,010: 1,330)$, te prema tome da mlade krmače sa manjom živom težinom daju sitniju prasad.

Tabela 1

Razvitak prasadi raznih rasa za 8 nedelja dojenja

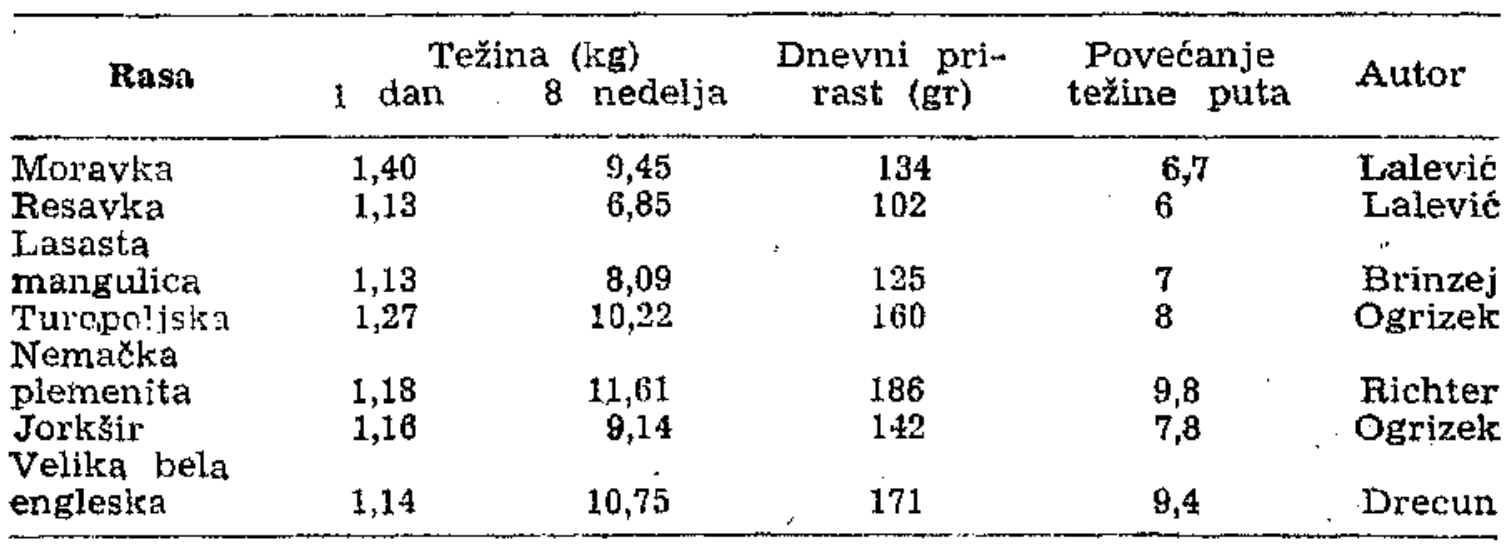

Ova tabela nam krazuje da se najbrže razvijaju prasad plemenitih rasa: velike bele engleske i nemacke plemenite. UU doba sisanja postižu najveću apsolutnu težinu $(10,75$ i $11,61 \mathrm{~kg})$, najveći dnevni prinast $(171$ i $186 \mathrm{gr}$ ) i najviše povećavaju početnu težinu $(9,4$ i 9,8 puta). Posle njih od domaćih rasa na prvo mesto dolazi turopoljska svinja $(10,22 \mathrm{~kg} 160 \mathrm{gr}$ 8 puta).

Tabela 2

Povećanje telesne težine prasadi velike engleske rase za 8 nedelja dojenja

\begin{tabular}{|c|c|c|c|c|}
\hline \multicolumn{2}{|c|}{$\begin{array}{l}\text { Starost u } \\
\text { nedeljama }\end{array}$} & Muška & Zenska & Prosecno \\
\hline \multicolumn{2}{|c|}{1 dan } & $\begin{array}{l}1,074 \pm 0,055 \\
2,343 \pm 0,060\end{array}$ & $\begin{array}{l}1,183 \pm 0,045 \\
2,334 \pm 0,046\end{array}$ & $\begin{array}{l}1,139 \pm 0,035 \\
2,337 \pm 0,037\end{array}$ \\
\hline II . & $"$ & $3,350 \pm 0,094$ & $3,358 \pm 0,069$ & $3,354 \pm 0,053$ \\
\hline III & $"$ & $4,262 \pm 0,107$ & $4,297 \pm 0,084$ & $4,283 \pm 0,066$ \\
\hline IV & $"$ & $5,267 \pm 0,118$ & $5,184 \pm 0,086$ & $5,217 \pm 0,068$ \\
\hline $\mathbf{v}$ & " & $6,076 \pm 0,147$ & $6,019 \pm 0,106$ & $6,042 \pm 0,085$ \\
\hline VI & $"$ & $7,430 \pm 0,187$ & $7,339 \pm 0,140$ & $7,375 \pm 0,111$ \\
\hline VII & " & $8,952 \pm 0,261$ & $8,835 \pm 0,229$ & $8,882 \pm 0,171$ \\
\hline VIII & $"$ & $10,838 \pm 0,318$ & $10,687 \pm 0,288$ & $10,748 \pm 0,212$ \\
\hline
\end{tabular}


Iz ove tabele izlazi da su prasci za sedam dana podvostručili početnu težinu (od 1,139 na 2,337), međutim, stvarno je 54,7 procenata prasadi podvostručilo težinu za ovo vreme, a ostalih 45,3 procenta u toku od 8 . do 10 dana.

Zenska grla su imala početnu težinu veću za $109 \mathrm{gr}$ od muških. U četvrtoj nedelji muška prasad u težini prevazilaze žensku i na kraju osme: nedelje prosečno su teža za 150 gr. Praktično, kod odlučivanja ne postoji. razlika u težini izmedu muške i ženske prasadi.

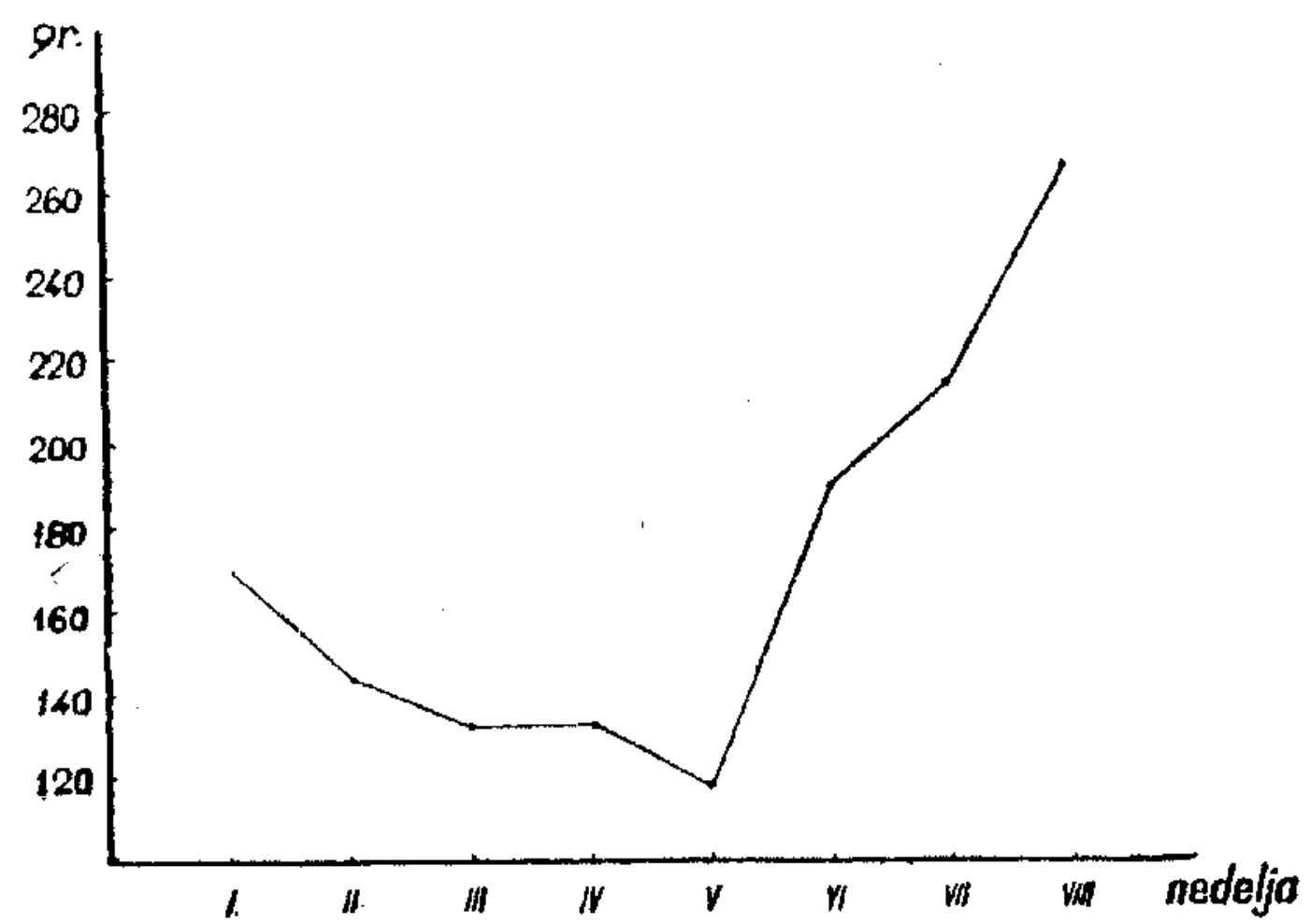

Dijagram br. 2. Dnevni prirast prasadi u gramima

Iz dijagrama br. 2 vidi se da je dnevni prirast u stalnom padu do kraja pete nedelje, kada se naglo diže. Iz ovoga izvodimo zaključak da krmace nisu imale dovoljno mleka da ishrane veliki broj prasadi sa znatnom težinom i da prasad od trece do zaključno pete nedelje nije. dobijala potpun obrok hrane. Tek kada je povećan obrok i kada su pox̌eli vił̌ da jedu, osetno se podigao dnevni prirast. Sliðne je rezultate dobio i $O \mathrm{~g} r$ i z e k kod turopoljske prasadi, s tom razlikom, sto je dnevni prirast počeo da raste od seste nedelje. 
Tabela 3

Apsolutni i relativni prirast telesne težine prasadi za vreme od 8 nedelja dojenja

\begin{tabular}{lrrrrrrrrr}
\hline \multicolumn{1}{c}{ Nedelja } & 1 dan & 1 & 2 & 3 & 4 & 5 & 6 & 7 & 8 \\
\hline $\begin{array}{l}\text { Prosečna } \\
\text { težina kg }\end{array}$ & 1,139 & 2,337 & 3,354 & 4,283 & 5,217 & 6,042 & 7,375 & 8,882 & 10,748 \\
$\begin{array}{l}\text { Apsolutni } \\
\text { prirast kg }\end{array}$ & & 1,198 & 1,017 & 0,929 & 0,934 & 0,825 & 1,333 & 1,507 & 1,86 \\
$\begin{array}{l}\text { Dnevni } \\
\text { prilast gr }\end{array}$ & & 171 & 145 & 133 & 133 & 118 & 190 & 215 & 267 \\
$\begin{array}{l}\text { Prirast u \% } \\
\text { od početne t. }\end{array}$ & 100 & 205 & 294 & $\mathbf{3 7 5}$ & 458 & 530 & 647 & 780 & 944 \\
\hline
\end{tabular}

Prosečni dnevni prirast u prve četiri nedelje izmosio je $146 \mathrm{gr}$, a $\mathrm{u}$ toku osam nedeija dojenja $171 \mathrm{gr}$. Na kraju cetvrte nedelje bila je težina 4,5 puta veća od porodne, na kraju osme nedelje 9,4 puta. U dijagramu pod 3 prikazano je povecanje telesne težine $\mathfrak{u}$ kilogramima $u$ toku osamnedelja dojenja.

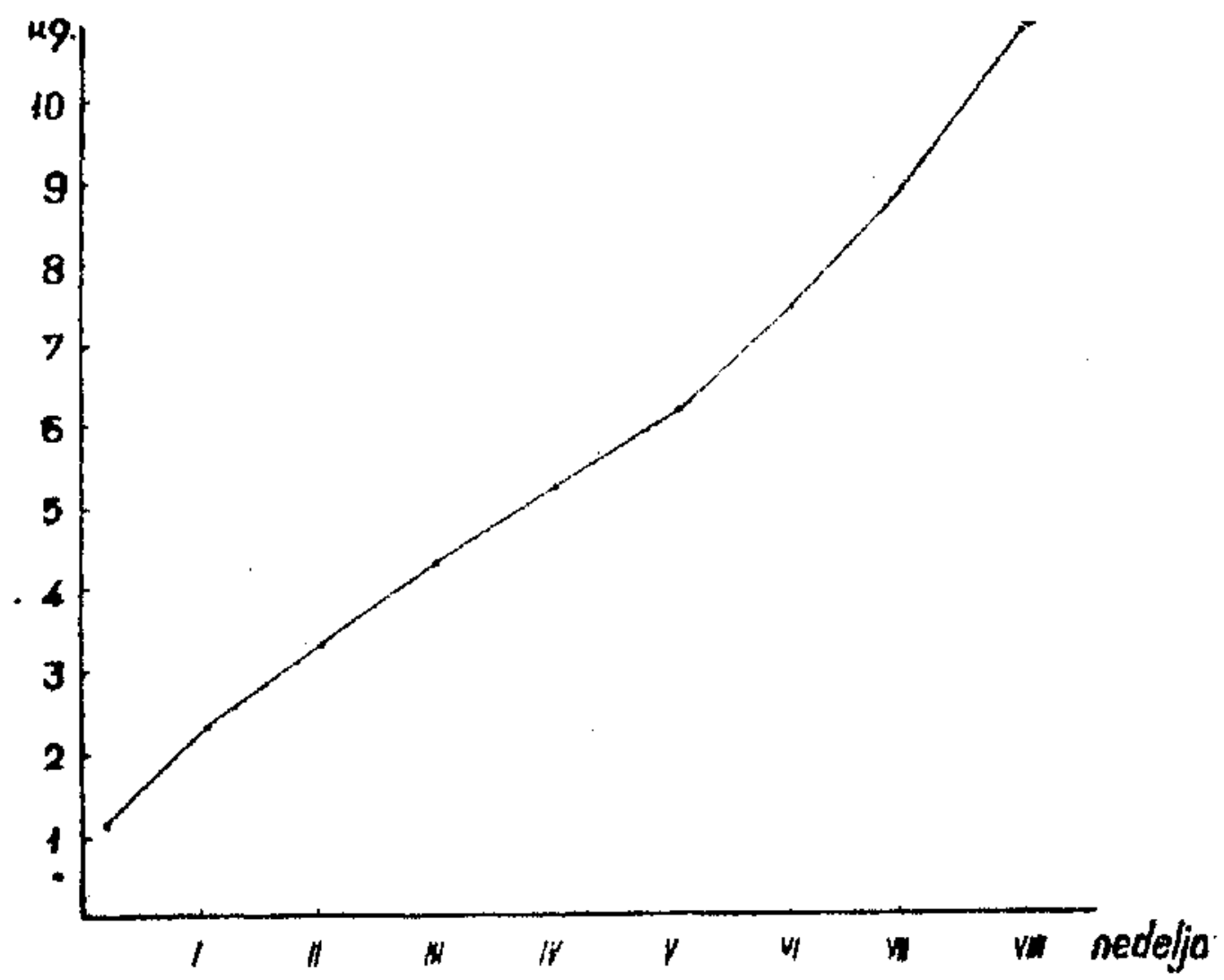

Dijagram br. 3. Povećanje telesne težine za 8 nedelja dojenja

Pored prosečne težine pojedinih grla takode je od velike važnosti: ukupna težina legla kod prasenja, u određenim vremenskim razmac ma u doba sisanja i kod odlučivanja. Z orn (16) postavlja kao normu da. 
prosečna težina dobrog legla treba da iznosi: kod prašenja $12-15 \mathrm{~kg}$, sa 4 nedelje $50-60 \mathrm{~kg}$, sa 8 nedelja $120-140 \mathrm{~kg}$. U tablici pod 4 navedeni su podaci o prosečnoj težini legla u doba sisanja raznih rasa svinja.

Tabela 4

Prosečna težina legla u doba sisanja raznih rasa svinja (kg)

\begin{tabular}{|c|c|c|c|c|c|}
\hline $\mathbf{R} \mathbf{a} \leq \mathbf{a}$ & $\underset{\text { orašenitu }}{\text { ICod }}$ & 4 nerdelise & $6 n+1 / \mathrm{e} j \mathrm{j}$ & 8 nedel ja & Autor \\
\hline $\begin{array}{l}\text { Turopoljska } \\
\text { Lasasta }\end{array}$ & 7,63 & 35,21 & - & 57,46 & Ogrizels \\
\hline mangulica & 6,99 & $42,7-64,7$ & $61,5-98,1$ & $89,0-147,0$ & Brinzej \\
\hline $\begin{array}{l}\text { Bela mangulica } \\
\text { Nemaxka plemenita }\end{array}$ & 7,57 & 31,40 & - & $74,00\left(^{*}\right)$ & Bielić \\
\hline $\begin{array}{l}\text { i oplemenjena } \\
\text { Velika }\end{array}$ & 10,45 & 52,59 & - & 110,75 & Glatze \\
\hline bela engleska & $\cdot 13,27$ & 54,26 & 76,70 & 113,76 & Drecun \\
\hline
\end{tabular}

*) 10 nedelja

Naši podaci približavaju se normama koje postavlja Z orn za plemenite rase svinja u dobrim uslovima držanja. Najmanju pcěetnu težinu legla imala je krmača br. 2 (prveskinja) sa 11 prasadi i težinom legla od $8,80 \mathrm{~kg}$. Na kraju osme nedelje ovo leglo je imalo težinu $91,70 \mathrm{~kg}$. Najveću početnu težinu $(16,70)$, kao i najveću težinu na kraju osme nedelje $(147,20)$ imalo je drugo leglo krmače br. 1 (sa 13 oprašenih i 12 odlučenih prasadi).

\section{Zaključak}

Velike bele engleske svinje, kao nazimice od 12 meseci, prenesene iz Bačke u Bosnu, kod Sarajeva, lako su se prilagodile novim životnim uslovima. Krmače su se redovno prasile i zadržale su visoku plodnost $(11,8)$ svojstvenu ovoj rasi. Prosečna težina prasadi kod prašenja zadovoljava $(1,139)$. Sa starošću i krupnoćom krmača povećava se težina jednodnevne prasadi: prasad iz I legla imaju prosečnu težinu $1,01 \mathrm{~kg}$, a prasad iz II legla $1,33 \mathrm{~kg}$. Prasci se brzo razvijaju i za vreme sisanja od osam nedelja dostižu težinu od $10,75 \mathrm{~kg}$ odnosno $133,76 \mathrm{~kg}$ prosečno po leglu.

Razvitkom industrijskih centara i gradova u NR BiF i podizanjem životnog stanđarda, povećavaju se zahtevi za namirnicama animalnog porekla. Znatan deo potreba treba da se podmiri svinjskim mesom i slaninom. Među mnogobrojnim kulturnim rasama engleske velike bele svinje daju najveću i najkvalitetniju produkciju. Uz to rano stasavaju i veoma dobro iskoriščavaju hranu, naročito ostatke kod prerade mleka (obrano mleko, mlaćenicu, surutku). To je od posebnog interesa u Bosni, gde se velika važnost daje podizanju govedarstva i ovcarstva (ovca će i dalje služiti za proizvodnju mleka dokle se ne podigne mlečnost krava). .Iz ovih razloga i na osnovu postignutih rezultata smatramo da je u desetogodisnjem orijentacionom programu unapređenja stočarstva rejonizacijom rasa dato pravilno mesto englesisim velikim belim svinjama. 


\section{ZUSA M M E FASSU NG}

\section{DIE INTENSITAT DES ZUWACHSES VON FERKELN DES GROSSEN ENGLISCHEN WEISSEN SCHWEINES WAHREND DER SAUGEZEIT}

Auf dem Versuchsgute der Fakultät für Forst- und Iarydwirtschaft ASlatina bei Sarajevo wurde im Frühjahr 1951 rund 1952 die Intensitüt des Zuwachses von Ferkeln des grossen englischen weissen Schweines während der Säugezeit innerhalb 8 Wochen untersucht. Die Muttersäue wurden im Alter von 12 Monaten auts der Bačka nach Slatina in andere klimatische Verhältnisse gebracht, wo sie sich rasch den neuen Lebensbedingungen anpassten. Es wurde der I. und II. Wurf von 3 Säuen, insgesamt 59 Ferkeln untersucht. Die durchschnittliche Fruchtbarkeit per Wurf betrug 11,8. Der. Prozentsatz an totgeborenen Ferkeln betrug $1,7 \%$, an totgeborenen und eingegangenen Ferkeln innerhalb der Säugungszeit von 8 Wochen $11,8 \%$. Beim Wurf betrug das Lebendgewicht der Ferkeln $1.139 \mathrm{~kg}$, mit 4 Wochen $5,217 \mathrm{~kg}$ mit 6 Wochen $6.042 \mathrm{~kg}$, mit 8 Wochen $10,748 \mathrm{~kg}$.

Der durchschnittliche tägliche Zuwachs in den ersten 4 wochen betrug $146 \mathrm{gr}$, und im Verlaufe von 8 Säugewochen $171 \mathrm{gr}$. Der tïgliche Zuwachs war von der 1 . Woche bis zum Ende der 5 . Woche $\left(118 \mathrm{gr}^{\prime}\right)$ im steten Abnehmen, worauf or nasch anstieg: in der 6 . Woche bis $z$ u $190 \mathrm{~g}$, in der 8 . Woche bis zu $267 \mathrm{gr}$. Daraus ziehen wir den Schluss, dass die Muttersäue nicht genügend Miłch hatten um eine grosse Zahl Ferkel zu ernähren und dass die Ferkel von der 3 . bis aur 5 . Woche nicht die notwendige Nahrungsmenge bekommen konnten. Als man die Nahrungsmenge erhöhte, war ein sichtbarer täglicher Zuwachs festzustellen. Innerhalb von 7 Tagen verdoppelte sich das Gewicht bei $54,6 \%$ Fetkel, und innerhalb von 10 Tagen bei den abrigen 45,3\%. Das druchschnittiliche Anfangsgewicht eines Wurfes betrug $13,27 \mathrm{~kg}$, am Ende der 4. Woche $54,26 \mathrm{~kg}$, an Ende der 6 . Woche $76,70 \mathrm{~kg}$, am Ende der 8. Woche $113,76 \mathrm{~kg}$. Während der Säugezeit verloren die Muttersäue $13,5 \%$ von ihrem Körpergewicht. Der geringste Verlust von $5 \mathrm{~kg}(2-9)$ wurde beim Säugen des ersten Wurfes festgestellt.

\section{LITERATURA}

1 Belić $J, O$ intenzitetu porasta prasadi lasaste mangulice, Godišnjak Poljoprivrednog fakulteta, 117-157, Beograd, 1949.

2 Brinzej IM. Prilog poznavanju lasaste mangulice, Poljoprivredina znanstvena smotra, sv. 12, 69-115, Zagreb, 1950 .

3 Ilancić $D$. O plodnosti zadruz̆nih benkšira u Pivnicama, Veterinarski arhiv, knjiga $11 \mathrm{sv}$. 10, 425-433, Zagreb 1941.

4 Kodinec G. Veličina legla $u$ odnosu na broj živo i mrtvo oprašene prasadi od krmača bijele engleske svinje, Vet. arh. XX sv, 1, 29-40, Zagreb 1950.

5 Ko dinec G. Klasifikacija rasplodnih kimača s obzirom na dojnost, Vet. arh. knjiga 9, sv. 2, 80-103, Zagreb 1939.

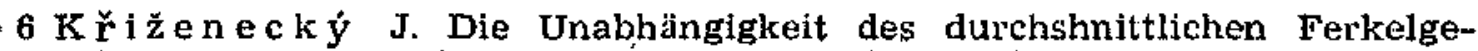
wichtes von der Wurfnummer, Zeitscharlft für Tierzüchtung und züchtungsbiologie, 50 Band, 208-225, Berlin 1941.

$7 \mathrm{~K} \check{\mathrm{r}} \mathrm{iženecký}$ J. Untersuchungen über den Einfluss des Alters beim ersten Wurf auf die Fruchtbarkelt der Sauen, Zeitschrift fijr Tierzüchtung und Ztächtungsbiologie, 52 Band, 209-229, Berlin 1941.

8 La leví D. Razvitak telesne težine prasadi svinje resavke, Stocarstvo br. 2, 82-86, Zagreb 1952. 
9 L a levic D. Porast težine prasadi svinje moravke u periodu sisanja, Arhiv za polj. nauke, God. V, sv, 8, 139-146, Beograd 1952.

10 Og rizek A. Prinos poznavanju razvoja turopoljske prasadi, Polj. znanstvena smotra sv. 4, 4-67, Zagreb, 1941.

11 Romić St. Prilog poznavanju nekih fizioloških i gospodarskih svojstava bijele mangutice, Vet. arh. XIII-6, 199-248, Zagreb 1943.

$12 \mathrm{Schmidt}$ J. Züchtung, Ernährung und Haltung der landw. Haustiere, $P$. Parey, Berlin 1945.

$13 \mathrm{Schmidt} J$. La uprecht E., Staubesand H. Untersuchungen über die Vererbung del' Trächtigkeitsdauer, des Geburtsgewichtes und der Zitzenanzahl beim Schwein, Zeitschrift für Züchtung, Band XXXVI, 55-100, Berlin 1936.

14 Smith W. Pork Production, Mac Millan Comp. New York 1950.

$15 \mathrm{~T}$ a v čar A. Biometrika u poljoprivredi, Zagreb 1946.

16 Z o n W. Schweinezucht, IV Aufl. Stuttgart, 1949. 